\title{
An Opinion on UNHCR Involvement in Hong Kong
}

\author{
by Simon Ripley
}

The Universal Declaration of Human Rights proclaims that everyone has the right to seek and to enjoy in other countries asylum from persecution. In the fortieth year of the Convention, the Hong Kong government has introduced an eligibility procedure for the determination of refugee status for Vietnamese asylum seekers arriving in the territory. The primary objective of the procedure was to deter asylum seekers. It was introduced because Western States have in recent years become less willing to resettle refugees from Hong Kong. There has also been an assumption made that most of those now arriving, do so for economic reasons.

The procedure came into effect on June 16, 1988. Since that date, 10,000 boat people have arrived and will be interviewed by the Immigration Service. The Immigration Service makes a decision on the asylum seekers's status according to the UNHCR definition of a refugee (as explained in the UNHCR Handbook). To date, of 313 cases examined by the Immigration Service only 2 have been found to be "deserving" of refugee status in their own right.

Clearly the theory is that a greater deterrent is presented to those still in Vietnam if fewer people are successful in their applications for asylum. It is with this in mind that the Immigration Service administers the procedure. Of perhaps greater deterrent value is the fact that all asylum seekers arriving since June 1988 and those who are determined not to be deserving of refugee status, are detained in closed detentions camps. They have no prospect of resettlement or freedom.
At the present rate, it is likely to take seven years to deal with the current case load. Once refused, applicants are classed as illegal immigrants and they are detained pending repatriation to Vietnam. There is in fact no plan to forcibly repatriate the Vietnamese and any such proposal is most unlikely to be forthcoming. Those refused therefore await an uncertain future in detention, with 1997 on the horizon. Or they can volunteer to repatriate. One is forced to ask the question how voluntary can a decision to repatriate be, when one is faced with such bleak alternatives.

It cannot be correct that so many people are still risking their lives and their futures. It cannot be right that the people leaving, whatever their motives, are undeserving of protection or even of basic human rights. If a policy such as this is so clearly unfair, is it possible for the UNHCR to work to improve it? Ought not the UNHCR be challenging the very existence of such a policy?

\section{The Agreement}

The statement of understanding, reached between the Hong Kong government and the UNHCR concerning the treatment of asylum seekers arriving from Vietnam in Hong Kong, came into effect from September 1988. It states that the Hong Kong government will apply appropriate humanitarian criteria for determining refugee status, taking into account the special situation of asylum seekers from Vietnam. The agreement provides a questionnaire designed by UNHCR to form the basis of Immigration Service interviews and to reflect the elements of the criteria used for determining status. In the agreement much emphasis is placed upon the UNHCR handbook as a means to interpretation of the 1951 Convention, but in essence, and in practice, a very rigid definition of refugee is used, i.e. well founded fear of persecution as applied in other states. The Hong Kong Immigration Service subsequently embraced this definition in a very inflexible way that probably was not foreseen in the agreement. UNHCR confirmed in the agreement that they had been consulted on the criteria to be applied and that it would brief immigration officers involved in the determination procedure. At this briefing UNHCR was satisfied that the criteria were to be applied in a generous manner although this later proved to be an unfounded assessment. Three months after the commencement of the agreement the Immigration Service declined UNHCR's offer of a further training session.

The agreement facilitated a procedure for cordial discussion between UNHCR monitoring officers and the Immigration Service. This was intended to establish broad agreement on the sort of cases which should be granted refugee status. This spirit of co-operation quickly deteriorated.

To some extent there was a tradeoff in the agreement, in that eligibility procedure was only part of the change in the treatment of refugees in Hong Kong. The Hong Kong government agreed to the immediate 
and progressive opening of the refugee centres which had been closed since the earlier deterrent policy, attempted in 1982. It is unclear to what extent UNHCR's involvement in monitoring the eligibility procedure was contingent on the liberalization of the closed centres.

\section{The Hong Kong Immigration Service}

It seems clear that the Hong Kong government has taken a policy decision to "screen out" asylum seekers. It has applied a very rigorous interpretation of the United Nations refugee definition, and their starting point is that new arrivals are economic migrants. These assumptions are supported by the statistical evidence, by conversations with the Immigration Service officials, by an examination of those 2 cases which have been "screened in" and theoretically in that the more "screened out", the greater the deterrent.

UNHCR monitoring offices found it hard to argue with Immigration Service decisions to "screen out" in many cases where such an argument was based on the information contained in the Immigration Service files. Often the file on a particular case contained so little information that no decision either way would normally be possible. The Immigration Service interview of the asylum seeker is of a very poor quality.

The interview is conducted in three languages. The immigration officer asks the questions on the questionnaire in Cantonese, this is translated by the official Hong Kong Government interpreter into Vietnamese and the response passed to the immigration officer.

The notes are then made by the immigration officer in English. The Hong Kong Government interpreters are required to pass a proficiency test, but their Vietnamese is often inadequate. All left Vietnam before
1975, and so have little knowledge of recent language usage under the current regime. All are ethnic Chinese and there are also regional language differences. Many immigration officers deviate from the questionnaire to ask more probing questions but some do not. It is quite common to see a questionnaire with ten or more consecutive negative responses, though it is hard to believe that an asylum seeker has absolutely nothing to say. Some of those who have been interviewed state that the immigration officer shouted at them and UNHCR's monitoring officers did witness this in some cases.

Without doubt the interview is not carried out in the most relaxing of atmospheres. From having spoken to the immigration officers, it is clear that the majority carry out the interview with the assumption that the asylum claim is bogus and that the applicant is an economic migrant. Questions are often aimed at finding discrepancies so as to discredit the applicant rather that to corroborate or consolidate information. In Hong Kong generally there is an atmosphere of hostility towards the Vietnamese and the "screening" procedure only serves to strengthen this.

Given the nature of the interview, there is great doubt as to the ability of the applicant to adequately express a well founded fear of persecution. Nevertheless, it forms the basis on which the Immigration Service makes a decision. The file is then passed to senior immigration officers and chief immigration officers to make an assessment and final decision. The file is minuted with their opinions and reasoning. The asylum seeker is then informed and can lodge an appeal within fourteen days. So far all those screened out have appealed. When the asylum seeker is informed of the decision to refuse, only in a small minority of cases are the applicants given reasons for the refusal. At this stage the file is passed to UNHCR, who are responsible for the preparation of grounds of appeal.

UNHCR can intervene at any time, if it feels there is a strong case to be made: These interventions and grounds of appeal are considered by the Immigration Service, who are then able to reverse their decision. If the decision is not reversed, the file moves up to the Security Branch, where grounds of appeal are considered. The final decision to refuse rests with the Governor of Hong Kong in Counsel. There is no independent body examining the file at any stage. There is no provision for a hearing or the making of oral representations.

\section{The United Nations High Commission for Refugees}

UNHCR entered into the agreement to monitor the screening procedure with an apparent lack of preparedness. Six consultants were hired as monitors, although no thought was given to the provision of interpreters. Much time was spent by the consultants hiring interpreters from abroad and at the time of writing only three were in post. This meant that only three consultants were able to monitor the Immigration Service interviews. As UNHCR was obliged to take on appeals, the consultants with interpreters were even more thinly stretched and were able to monitor less than 20 per cent of the interviews. The Hong Kong Law Society agreed to provide legal services for the preparation of grounds of appeal. Due to the expense of their services, their inexperience in refugee law and lack of knowledge on Vietnam, and the fact that they endorsed many immigration decisions rather than challenged them, UNHCR decided to cease the arrangement. This meant that UNHCR's consultants for a short time did appeal interviews with those screened out to prepare grounds of appeal. Whilst this gave consultants a wealth of information on Vietnam and a better understanding of the 
reasons for leaving Vietnam, it did mean they were over-stretched. The lack of interpreters also proved a constant barrier to full working capacity.

UNHCR proceeded to hire four additional consultants to prepare appeals under the aegis of a voluntary organization based in Hong Kong. At the time of writing, no appeals had been decided by the security branch.

At an early stage UNHCR consultants contacted local lawyers on the possibility of making applications for Judicial Review. It was felt that the procedure, as described, inadequately protected the refugee's rights and the application of UK precedent case law, though Judicial Review of the procedure was one means by which the process could be improved. Authoritative legal opinion on the prospects for Judicial review suggested that the failure of the screening procedure to permit legal representation at the initial Immigration Service interview stage fell short of the civilized standards required under the Convention and to be expected of the Hong Kong government. Judicial Review proceedings would have a reasonable prospect of success. A fairer procedure, it was suggested, would allow a legal representative to make an interview with the asylum seeker contemporaneous to the Immigration Service interview. Representation would then be made to the Immigration Service, which would make a decision on eligibility in the light of its own assessment and the legal representations. The discrepancies that inequitably arise could then be ironed out before a decision is made.

UNHCR made clear to the consultants however that Judicial Review would not be appropriate at such an early stage in the policy and, besides, UNHCR would not want to be seen to be directly endorsing an application for Judicial Review in a confrontation with the Hong Kong government.
Consultants found that when they made appeal interviews with those "screened out", substantial new information came to light that the Immigration Service interview had failed to obtain. When faced with this new information, the Immigration Service did undertake to re-interview the appellant. This however would further prolong the process beyond the seven years suggested above. More fundamental to the spirit in which the process was functioning is that great doubt was cast upon the new information by the Immigration Service given that it came after the refusal and after those refused had time to talk to friends and to UNHCR's consultants.

At one stage a senior immigration officer stated to one of the consultants that the Immigration Service could neither trust UNHCR nor its interpreters not to feed the asylum seekers with a good story to strengthen their cases.

UNHCR had a number of meetings with senior officers at the Immigration Department intending to establish a dialogue as to which cases UNHCR felt were deserving of refugee status. It was also hoped that procedures, interviewing techniques, background information on Vietnam, etc. could be improved. These meetings were held in an atmosphere of polite diplomacy through they bore little fruit in terms of any improvement in the recognition rate. Following high level missions to Hong Kong by staff from Geneva, the High Commissioner made diplomatic advances to the Hong Kong Government, stating that current practices and recognition rates were unacceptable. It remains to be seen what response this will elicit.

\section{The Refugees}

For those seeking asylum who have already been detained since June 1988, conditions in detention camps have deteriorated. In Chimawan and Hei Ling Chau, the camps where screening has been taking place, an atmosphere of insecurity and hopelessness has grown up. There has been fighting in both camps. Ostensibly this is between people from Haiphong and people from Quang Ninh but certainly there are underlying factors. Some say there are criminal elements in the camps who fled to avoid prosecution in Vietnam, or who were released from jails there. All say that people in detention have nothing to lose, they fear justifiably that they will be screened out, and so certain elements establish protection rackets to intimidate other inmates. Many people have been injured in the fighting, some very seriously.

At the start of February asylum seekers started to boycott the Immigration Service interviews and UNHCR appeal interviews. They feel there is no point in attending and hope that this protest will express their anger at this unfair system. At a meeting organized to discuss these issues, refugees in Chimawan told UNHCR consultants that they stood together in their search for asylum, that all or none should be recognized as refugees. They asked UNHCR nol to become involved in supporting individual cases, but to support them en masse.

Conditions in the camps are very poor and crowded. There is no privacy, little education provision and limited recreation facilities. A considerable proportion of the camp population are children, growing up behind double high fences topped with barbed wire. For the lengthy time periods expected, these conditions are quite unacceptable.

There is a large body of opinion which argues that UNHCR should have fought more strongly the closed camp deterrent policy introduced in Hong Kong in 1982. As a deterrent, it did not work but did cause unnecessary suffering for a large number of people. It is hard to see anything of benefit to asylum seekers in the policy introduced by the Hong Kong government in 1988. Given that it is not possible to deport those 
screened out back to Vietnam since the Vietnamese government refuses to allow forced repatriation; given that it is not safe to return people to Vietnam against their will due to threats of further persecution against them; given that it is deemed necessary for UNHCR to monitor even those that return voluntarily to see that they are not prejudiced; and, finally, given that illegal departures from Vietnam are seen as a punishable crime against national security, it does seem premature to introduce any sort of eligibility procedure. It is doubtless true that many of those detained since June 1988 are not refugees within the strict UNHCR definition, nevertheless, it is not possible and not safe to return them. Accordingly, they must still be given protection and at the very least temporary asylum pending safe repatriation or resettlement elsewhere.

Since the procedure as outlined above is so unfair, less than one percent have been given the protection of refugee status and the process takes several years, it is disgraceful that UNHCR condones the detention of 10,000 innocent people in such inhuman conditions. Detention of asylum seekers has been in principle condemned by UNHCR, yet there appears to be very little willingness to challenge detention in Hong Kong.

Even if the process by which the refugee definition is applied were fair, and an attempt was genuinely made to find those with a well founded fear of persecution for Convention reasons, there must still be considerable doubt about the terms of the definition itself, and indeed the appropriateness of applying any definition at all in such a situation of a large scale influx. Many applicants do not fall within the definition and a perfunctory examination of cases might elicit primarily economic reasons for departure from Vietnam. This, however, is a naive assessment, but it is one which those in the Immigration
Service in Hong Kong have found easy to exploit in making decisions to refuse asylum.

Many asylum seekers experience harassment, discrimination and deprivation of the right to earn a living as a result of having been classified as bad elements or as counter-revolutionary. This can be due to either relatives before them who had links with the South Vietnamese army, the United States presence, or the French Colonial presence, or due to having made previous escape attempts. As a result of this classification, families are subject to capricious treatment by local authorities, children may be removed from school, parents may be denied permission to go fishing or to gain access to local co-operatives. As a result, they are forced into private enterprise, and this in turn is frowned upon and access to goods at official prices can be denied. This forces reliance on a black market, and this is illegal; so goods obtained can be seized.

There appears to be a cycle of oppression of which the above is but a brief example. Because Vietnam is a very poor nation and has a very restrictive and oppressive political system, most persecution of those leaving does take place on an economic level. Those with any power to persecute do so in part for their own economic gain, and because they too are poor. Bribery and corruption are therefore rife, but if one looks below the surface, there are frequently quasi-political elements beneath. To say that the Vietnamese are leaving simply for better economic opportunities misses this point entirely. People leaving for lack of religious freedom and those who refuse to fight in Kampuchea are also part of the case load. This religious aspect is well documented and the occupation of Kampuchea has been condemned by the United Nations itself.

For all of these reasons, the UNHCR definition is inappropriate. Those now arriving are in need of protection and durable solutions. It is wrong to use the 1951 definition the cornerstone of UNHCR's existence, as a means by which to deter asylum seekers. Countries of resettlement must continue to provide asylum outside of Hong Kong, but more importantly, emphasis must be turned to Vietnam, to examine the reasons why people are still leaving in such large numbers. It is contrary to place the burden of the solution on the people already in need of assistance, without addressing the reasons for their departure. Greater efforts should be made to bringing Vietnam back into the international community, to improving the economic situation and human rights in the country. "Screening" can only be applied when it is possible and safe to return those determined not to be refugees to their country of origin. "Screening" can only be functional when it is procedurally fair.

Essentially, UNHCR ought never to have agreed to participate in this policy. It is doubtful whether continued involvement will improve a fundamentally unjust procedure. To condone government policies of this nature will only serve to spread the sort of restrictive measures we are witnessing in Europe and North America to other regions. Since the policy requires the long term detention of large numbers of people, it is unlikely that other states in South East Asia currently turning away boat people, will change their practice. If UNHCR is to retain credibility as a humanitarian organization working to protect asylum rights, it must challenge governments where injustice is done, rather than condone that with which it does not agree.

Simon Ripley was legal consultant to the UN refugee commission until February 1989, when he resigned and wrote the opinion which we now publish (the italics are ours). He is now working with the United Kingdom Immigrants Advisory Service. 


\section{News in Brief}

- Immigration Minister Barbara McDougall issued special minister's permits to refugee claimants Hussein Mohamoud from Ethiopia and Nasrin Peiroo from Iran, whose claims were initially rejected at preliminary hearings. This followed reports that refugee claimants from Somalia, India and Nigeria, deported earlier on from Canada, could not be located after their departure by concerned monitoring groups.

- Forty-four new members have been appointed to the Immigration and Refugee Board chaired by Gordon Fairweather to deal with the refugee backlog. Over 115,000 claims, which had not been determined before the new refugee determination process came int effect on January 1,1989 , await to be resolved. Twenty-eight of the new members will be working in the Toronto Regional Office, since most backlog claimants reside in the Metropolitan Toronto area. Twelve members have been appointed to the Montreal Regional Office and four to the Vancouver Regional Office. Twomember panels, consisting of a member of the Immigration and Refugee Board and an Immigration Adjudicator, will hear each claim for refugee status and apply the definition of a Convention Refugee to the facts and circumstances of each case. It suffices for one of the two-panel members to rule that the claim has a credible basis to ensure the confirmation of refugee status. The Board will begin hearings after the completion of an intensive training course for the new members.

- Three new members have been appointed to the Convention
Refugee Determination Division (CRDD) of the Immigration and Refugee Board. These include Centre for Refugee Studies research associate Lisa Gilad, who will be reporting to the Montreal Regional Office from Newfoundland; Paul Matarazzo, who will be reporting to the Toronto Regional Office from Thunder Bay; and Sherry Makarewicz, who will be reporting to the Calgary Regional Office from Edmonton. These new additions bring the total member contingent of the Board to 167 , including the Chairman, of whom 145 are assigned to the CRDD and 21 are assigned to the Immigration Appeal Division.

- On April 10, a 55-foot wooden sailboat with 261 passengers, including 19 children and seven pregnant women, was stopped by the Coast Guard just a few yards from Miami's luxury Fisher Island community. The passengers were immediately interned by the INS at the Krome Avenue Detention Center, where they joined sever hundred other Haitians, including boat people who had reached the US in December. Following intervention by the Haitian Refugee Center, the children and pregnant women were released to relatives, but many family members remain in detention. By the middle of April, some 750 people, most of them Haitians, were being held in Krome, a facility designed to house 525. [from Haitilnsight, Vol. 1, No. 1 (May 1989), p. 6]

\section{ThE VietnAmese Association of TORONTO and \\ The Greater Vietnamese Refugee ASSISTANCE COMMITTEE}

request the honour of your presence at the tenth anniversary celebration of Operation Lifeline and reunion of former sponsors, former refugees and others involved in the assistance of the Boat People

on

Sunday, June 25th, 1989 3:00 pm to $6: 00 \mathrm{pm}$

at

Holy Rosary Church

354 St. Clair Avenue West, Toronto (next to St. Clair West Station) 